\title{
Manajemen N-IOM (Manajemen Neurologi-Intraoperatif) pada Eksisi Tumor Myelum dan Dekompresi Stabilisasi Servikal C2-C6
}

\author{
Andri Rusly, Buyung Hartiyo Laksono \\ Departemen Anestesiologi \& Terapi Intensif Fakultas Kedokteran Universitas Brawijaya-RSUP Dr. Saiful Anwar \\ Malang
}

\begin{abstract}
Abstrak
Pemantauan neurofisiologis intraoperatif (N-IOM) berkembang menuju standar perawatan untuk meminimalkan risiko cedera jalur saraf selama prosedur bedah saraf. Pentingnya tidak hanya terletak dalam mendiagnosis cedera pada periode perioperatif untuk pasien yang berisiko tinggi serta komplikasi neurologis dari operasi tetapi juga dalam menciptakan kesempatan untuk menyelamatkan jaringan saraf yang berisiko sebelum kerusakan menjadi ireversibel. Operasi pada tulang belakang merupakan salah satu operasi dengan tingkat resiko tinggi untuk mencederai jaringan sehat sekitar, oleh sebab itu teknik anestesi dengan N-IOM akan sangat membantu mengurangi komplikasi durante operasi. Beberapa penelitian sebelumnya meneliti tentang kombinasi yang berbeda dari teknik N-IOM (seperti somatosensory evoked potentials [SEPs], motor evoked potentials [MEPs], direct wave, freerunning electromyography). Hasilnya didapatkan bahwa penggunaan N-IOM multimodal untuk operasi tumor sumsum tulang belakang memberikan hasil yang lebih baik daripada penggunaan N-IOM dengan satu teknik. Teknik N-IOM dengan menggunakan sedasi seperti propofol dan dexmedetomidine yang dikombinasikan dengan opioid seperti fentanyl dapat menjaga kedalaman anestesi pasien tanpa mengganggu sinyal N-IOM itu sendiri. Untuk memaksimalkan nilainya, penting tim operasi untuk memiliki pemahaman dasar tentang prinsip-prinsip neuromonitoring dan ahli anestesi untuk memahami bagaimana hal itu dapat dipengaruhi oleh anestesi. Oleh karena itu, diperlukan teknik anestesi yang optimal dimana hemodinamik pasien tetap terjaga selama pembedahan dan monitoring IOM tetap dapat dilakukan.
\end{abstract}

Kata kunci: eksisi tumor myelum, N-IOM, tehnik anestesi

JNI 2022; 11 (1): 40-8

\section{Management N-Iom (Neurology-Intraoperative Management) at Tumor Myelum Exition Decompression and Stabilization Cervical C2-C6}

\begin{abstract}
Intraoperative neurophysiological monitoring (IOM) is advancing towards the standard of care for the risk of neural pathway injury during neurosurgical procedures. The importance lies not only in finding a diagnosis in the perioperative period for high-risk patients as well as neurologic complications from surgery but also in creating opportunities to salvage neural tissue before the damage becomes irreversible. Surgery on the spine is one of the operations with a high level of risk for injuring the surrounding health tissue, therefore the anesthetic technique with N-IOM will greatly help reduce complications during surgery. Several previous studies investigated different combinations of N-IOM techniques (such as somatosensory evoked potentials [SEPs], motor evoked potentials [MEPs], direct wave, free-running electromyography). The results showed that the use of multimodal N-IOM for spinal cord tumor surgery gave better results than the use of a single technique N-IOM. N-IOM techniques using sedatives such as Propofol and Dexmedetomidine in combination with Opioids can maintain the depth of anesthesia without interfering with the N-IOM signal itself. To maximize its value, it is important for the operating team to have a basic understanding of the principles of neuromonitoring and the anesthesiologist to understand how it can be affected by anesthesia. Therefore, an optimal anesthetic technique is needed where hemodynamics is maintained during surgery and IOM monitoring can still be performed.
\end{abstract}

Key words: anesthetic technique, N-IOM, myelum tumor excision

JNI 2022; 11 (1): 40-8

This article is licensed under a

Creative Commons Attribution-NonCommercial-ShareAlike 4.0 International License.

CAndri Rusly, Buyung Hartiyo L (2022) under the CC-BY-NC-SA license 


\section{Pendahuluan}

Perbaikan dalam teknik bedah semakin mengarah pada reseksi tumor yang lebih agresif. Namun, meskipun dikerjakan oleh ahli bedah yang paling terampil, operasi tulang belakang memiliki risiko yang melekat pada kerusakan neurologis pasca operasi, terutama pada operasi-operasi yang berubungan dengan keganasan tulang belakang. Pemantauan neurofisiologis intraoperatif(IONM) memungkinkan ahli bedah melanjutkan dengan manuver yang lebih agresif untuk pengangkatan tumor secara total. ${ }^{1}$ Ada berbagai penelitian tentang pemantauan yang efektif, berdasarkan kepentingan klinis penggunaan Teknik N-IOM untuk operasi tumor intramedullary tulang belakang. Namun, pedoman khusus tentang teknik N-IOM belum ditetapkan. Beberapa penelitian sebelumnya meneliti tentang kombinasi yang berbeda dari teknik N-IOM (seperti somatosensory evoked potentials [SEPs], motor evoked potentials [MEPs], direct wave, freerunning electromyography), dan menekankan penggunaan $\mathrm{N}-\mathrm{IOM}$ multimodal untuk operasi tumor sumsum tulang belakang yang aman. Ada kontroversi mengenai teknik kombinasi N-IOM tertentu, tetapi mereka menemukan pemantauan potensi motorik dan somatosensori gabungan paling sering digunakan untuk operasi tumor sumsum tulang belakang. ${ }^{1,2}$

Banyak modalitas yang bisa digunakan dalam pemantauan N-IOM, dan mereka dapat diklasifikasikan menjadi 2 jenis: 1) Deteksi aktivitas spontan, seperti electroencephalography (EEG) dan electromyography (EMG), dan 2) Pengukuran respons listrik yang ditimbulkan dari jalur saraf tertentu setelah stimulasi aktif. Contoh jenis yang terakhir termasuk potensi membangkitkan somato sensory evoked potential (SSEP), potensi membangkitkan motor evoked potential (MEP), dan potensi membangkitkan pendengaran batang otak, brain auditory evoked potential (BAEP). Modalitas ini dapat digunakan secara terpisah atau kombinasi tergantung pada struktur yang berisiko selama operasi. ${ }^{3}$

Secara teoritis, menggunakan kombinasi MEP dan SSEP untuk semua operasi tumor sumsum tulang belakang akan menjadi yang paling sensitif untuk mengurangi komplikasi neurologis pasca operasi. Namun, masalah biaya dan waktu menjadi salah satu poin minus penggunaan teknik ini. ${ }^{1}$ Ada banyak penelitian tentang N-IOM dan operasi tulang belakang, tetapi penelitian yang secara khusus berfokus pada kasus tumor sumsum tulang belakang tidaklah banyak ditemukan. Lebih khusus lagi, akan lebih sedikit ditemukan penelitian yang menguji efektifitas Modalitas N-IOM tertentu berdasarkan type tumor medula spinalis (tipe anatomis dan patologis).

\section{Kasus}

\section{Anamnesa}

Pasien berusia 14 tahun. Pasien mengeluhkan nyeri pada leher dirasakan sejak 10 bulan yang lalu. Nyeri dirasakan terus menerus. Nyeri leher disertai dengan keluhan sulit menggerakkan tangan kiri sejak 6 bulan yang lalu. Semakin lama semakin berat sampai tidak bisa digerakkan sama sekali sejak 1 bulan yang lalu rasa kebas tidak dirasakan pasien di ketiga anggota gerak lain. Pasien juga menyangkal adanya riwayat jatuh atau trauma yang lain. Pasien juga menyangkal adanya riwayat minum obat-obatan dalam waktu yang lama dan juga menyangkal adanya riwayat sakit tuberculosis. Pasien menyangkal adanya riwayat hipertensi, dibetes mellitus maupun riwayat allergi sebelumnya. Pasien juga menyangkal pernah dilakukan operasi sebelumnya.

\section{Pemeriksaan Fisik}

Pada saat preoperative visite didapatkan hasil pemeriksaan fisik sebagai berikut:

B1. Airway paten nafas spontan, buka mulut 3 jari, gigi palsu (-), RR 16-18 x/menit, $\mathrm{SpO}_{2} 98 \%$ Room Air vesiculer +/+, ronki -/-, wheezing -/-, gerak leher flexi $(+)$, extensi $(+)$

B2. Akral Hangat Kering Merah (+), tekanan darah 105/80mmHg Capillary Refill Time $<2$ detik, laju nadi $94 \mathrm{x} /$ menit, reguler (+), kuat angkat $(+)$, S1-S2 tunggal, reguler, murmur (-), gallops (-)

B3. GCS 456 , diameter pupil $3 \mathrm{~mm} / 3 \mathrm{~mm}$, isokor, reflek kornea $+/+$

Dari pemeriksaan motorik didapatkan C5 
elbow flexion 5/1, C6 wrist extension 5/1, C7 elbow extension 5/1, C8 finger flexion 5/1, T1 finger adduction 5/1. Pada segmen lumbosacral didapatkan L2 hip flexion 5/5, L3 knee extension $5 / 5$, L4 ankle dorsoflexion 5/5, L5 great toe extension 5/5 dan S1 ankle plantarflexion 5/5. Pada pemeriksaan sensoris: Sensoris C2 sampai S2 tidak ada kelainan yang bermakna dengan skala $2 / 2$

B4. BAK $(+)$ spontan

B5. Bising Usus $(+)$ Normal, distended abdomen $(-)$, nyeri tekan $(-)$

B6. Edema (-/-), sianosis (-)

\section{Pemeriksaan Penunjang Preoperatif}

\begin{tabular}{l} 
Dl: $15,6 / 6,93 / 47,4 \% / 221.000$ \\
Ppt:10,1/11,4/0,97 \\
Aptt:25,7/24,7 \\
Ot/pt: $22 / 15$ \\
Alb: 4,36 \\
Gds: 103 \\
Ur/Cr: $15,5 / 0,66$ \\
\hline
\end{tabular}

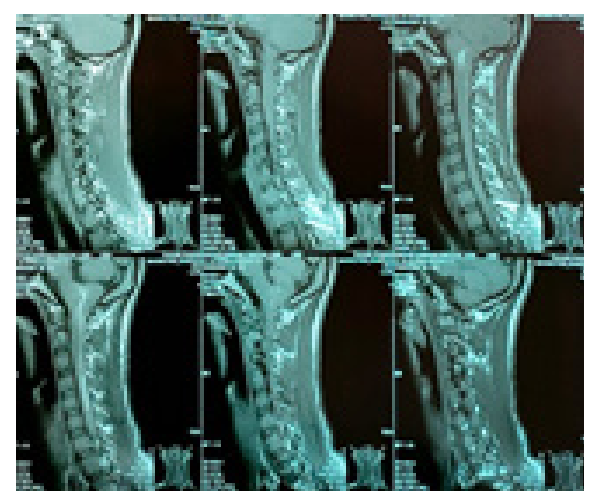

Gambar 1. MRI Kepala + Kontras, massa solid intramedullar setinggi intracranial $(1.9 \mathrm{~cm}$ di atas foramen magnum) hingga $\mathrm{C6}$, sugestif Ependymoma dengan perdarahan intratumoral (early subakut) DD astrocytoma spinal syringomelia di level C6-T1

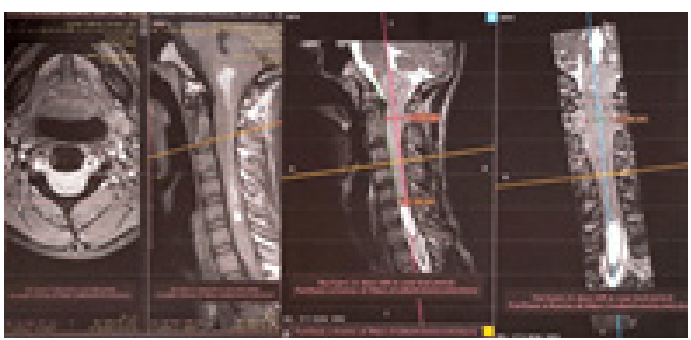

Gambar 2. Paracervical Muscle Spasm
Pengelolaan Anestesi (Durante Operasi)

Pasien direncanakan tindakan eksisi tumor dan dilanjutkan dekompresi + instrumentasi setinggi C1-C6. Dari kesimpulan preoperatif pasien didapatkan assasement ASA 3 Malignancy myelum intramedullary + Monoplegia extremitas superior sinistra. Pasien direncanakan dengan teknik anestesi anestesi umum brain proteksi dengan posisi prone durante operasi. Pasien juga akan dilakukan monitoring durante operasi oleh dokter neurologist dengan N-IOM (NeurologyIntra Operative Monitoring). Pasien dilakukan anestesi umum dengan menggunakan midazolam $2,5 \mathrm{mg}$, fentanyl $150 \mathrm{mcg}$, propofol $100 \mathrm{mg}$, lidocaine $50 \mathrm{mg}$ dan rocuronium $50 \mathrm{mg}$. Saat dilakukan induksi anestesi tidak didapatkan gejolak hemodinamik yang berarti. Tensi terukur 118/76 mmHg dengan nadi 76x/menit. Setelah dilakukan induksi anestesi, dilanjutkan dengan pemasangan vena sentral sebagai akses dan arterial line Sebagai pemantauan invasif. Setelah pemasangan pemantauan invasif selesai maka dilanjutkan untuk memposisikan pasien keposisi prone. Monitoring ketat hemodinamik baik sebelum posisi prone dan sesudah memposisikan prone pasien. Tindakan selanjutnya adalah pemasangan elektrode dan pacing-pacing sesuai dengan dermatome yang dkerjakan oleh dokter neurologist untuk kebutuhan N-IOM durante operasi.

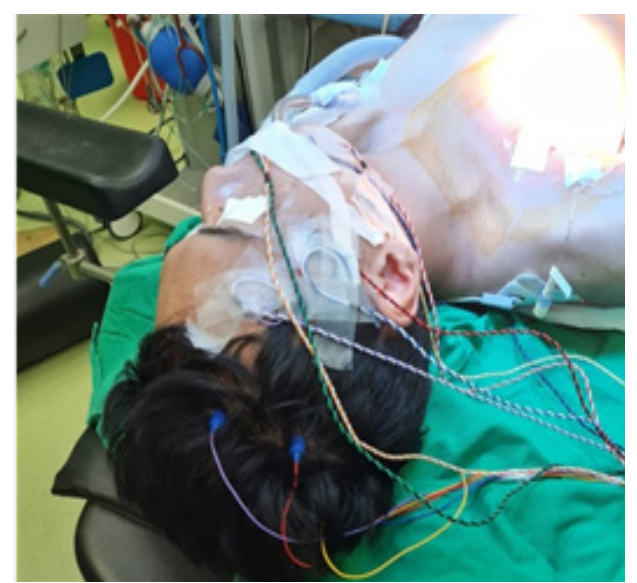

Gambar 3:.Proses Pemasangan IOM

Setelah pemasangan elektrode dan pacingpacing selesai, maka dilanjutkan pengecekan baseline pasien terutama SSEP dan MEP sebagai 


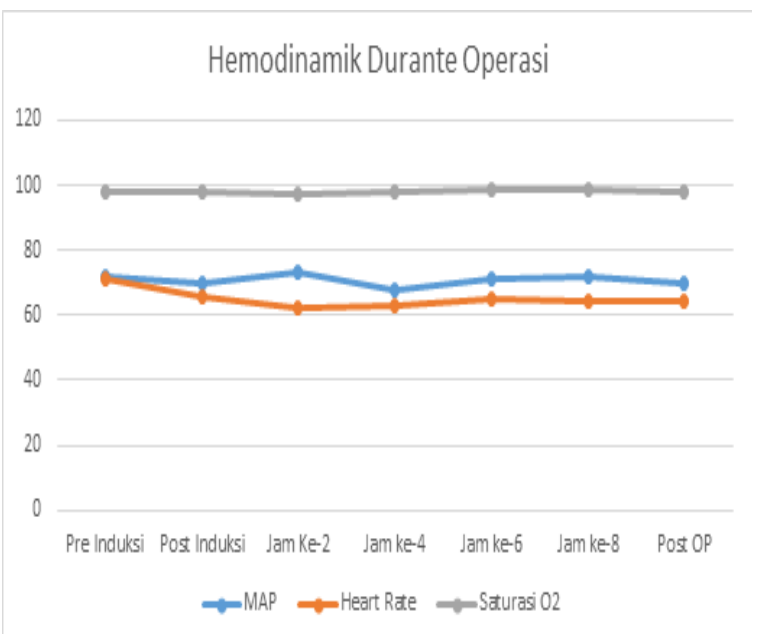

Grafik 1. Hemodinamik durante Operasi

pembanding selama durante maupun post operasi. Ditemukan bahwa MEP pada extremitas superior sinistra tidak ditemukan saat pengecekan baseline. Hal ini memang sesuai dengan klinis pasien dimana pasien mengeluhkan tangan kiri yang tidak bisa digerakkan sama sekali. Saat durante operasi dilakukan rumatan sedasi dan analgesia dengan teknik murni Total Intra Venous Anasthesia (TIVA) dengan menggunakan agen sedasi propofol $250-350 \mathrm{mg} / \mathrm{jam}$, fentanyl $50-100 \mathrm{mcg} / \mathrm{jam}$ dan dexmedetomidine $0,3-$ $0,7 \mathrm{mcg} / \mathrm{kgbb} / \mathrm{jam}$ Pelumpuh otot dan anestetika inhalasi tidak kami gunakan saat durante operasi. Hemodinamik durante operasi yang mencapai 10 jam didapatkan dalam kondisi stabil. Tidak pernah didapatkan swing hemodinamik yang bermakna. Mean Arterial Pressure (MAP) pasien durante operasi berkisar antara $70-72 \mathrm{mmHg}$ dengan laju nadi pasien terjaga di angka 64-70x/ menit. Perhatian khusus pada pasien ini adalah saat mulai dilakukannya insisi tumor myelum. Diperlukan koordinasi yang tepat antara tim anestesi, tim neurologi dan operator bedahnya. Monitoring kedalaman anestesi sangat diperlukan untuk menjaga pasien tersedasi dengan adekuat, tidak terlalu dangkal yang menyebabkan pasien bisa bangun durante operasi dan juga tidak terlalu dalam sehingga mengganggu monitoring neurophysiologi dari tim N-IOM Neurologi.

\section{Durante Operasi}

Hemodinamik pasien post induksi sampai hampir 10 jam pengerjaan tidak didapatkan swing hemodinamik yang berarti. Tekanan arteri rerata pasien bertahan disekitaran $68-75 \mathrm{mmHg}$ dan laju nadi pasien masih disekitaran 60-70x/menit. Tidak ada periode desaturasi, hipotensi maupun bradikardia. Pasien cenderung tenang dan tidak terjadi lonjakan hemodinamik yang berarti.

Monitoring fungsi-fungsi saraf dilakukan secara ketat terutama saat tindakan operator yang beresiko merusak saraf-saraf yang masih sehat. Monitoring terutama ditujukan pada gelombang SSEP dan MEP. Selain itu juga dilakukan monitoring untuk gelombang EEG, EMG dan TOF. Diharapkan pemantauan fungsi-fungsi saraf pasien bisa dilakukan secara realtime untuk mengurangi resiko cedera saraf durante operasi. Durante operasi terdapat waktu dimana terjadi komunikasi antara neurology dengan operator, dimana dokter neurologist mengingatkan

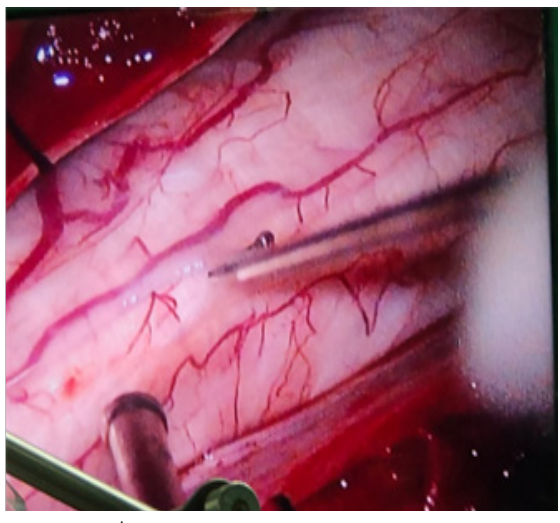

A

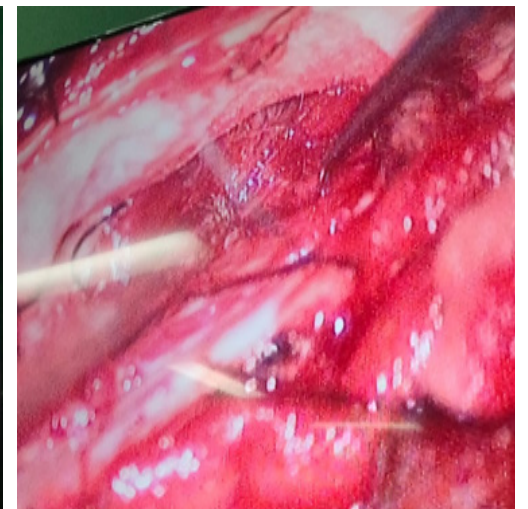

B

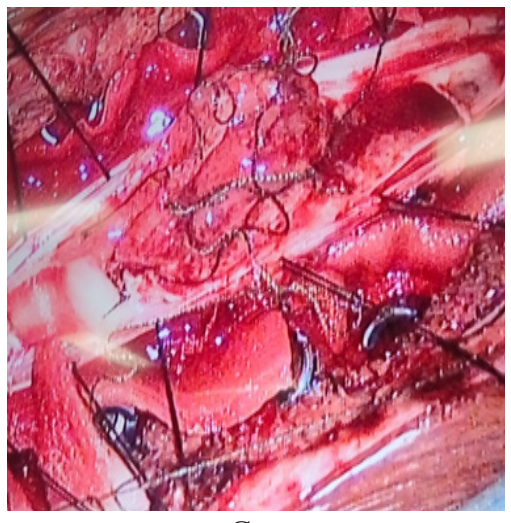

C

Gambar 4. A) Expose duramater B) Incisi Duramater C) Incisi Tumor Myelum 
operator saat muncul gelombang tersensitisasi saat durante tindakan operator. Operasi berlangsung selama 10 jam dimana target operasi yakni eksisi tumor setinggi C1-C6 dan dilakukan dekompresi dan instrumentasi setinggi cervical 2-6. Perdarahan durante operasi terhitung $800 \mathrm{cc}$ dengan balance cairan sekitar -150cc. Monitoring $\mathrm{N}-\mathrm{IOM}$ dikerjakan dari awal exici sampai selesai. Didapatkan kesimpulan akhir dari monitoring N-IOM adalah SSEP tidak didapatkan perubahan durante operasi (seperti pengukuran baseline awal), MEP tangan kiri tidak muncul sejak awal operasi namun MEP tangan kanan sedikit menurun dibandingkan dngan baseline awal.

\section{Pengelolaan Pascabedah}

Pascabedah operasi pasien dilakukan perawatan di ICU dengan menggunakan ventilator (Mode Ventilator PSIMV RR 14 Pins 5 Psupp 5 PEEP 3 Fraksi 40\%) dengan saturasi terukur $98 \%$, sedangkan parameter kardiovaskular didapatkan Nadi $82 \mathrm{x} /$ menit dengan tekanan darah 118/76. Pasien Dilakukan pemeriksaan penunjang seperti laboratorium post operasi. Dari pemeriksaan laboratorium post op didapatkan HB yang menurun namun masih dalam batas normal (Dl: 10,2/13.800/30,8\%/139.000) dengan serum elektrolit yang juga masih dalam rentang normal (serum elektrolit: 135/4,27/111). Dengan pendarahan sekitar $800 \mathrm{cc}$ memang didapatkan penurunan albumin menjadi 2,58. Sedangkan parameter faal ginjal dan faal pembekuan masih dalam batas normal (PPT: 12,4/11,4/1,2;

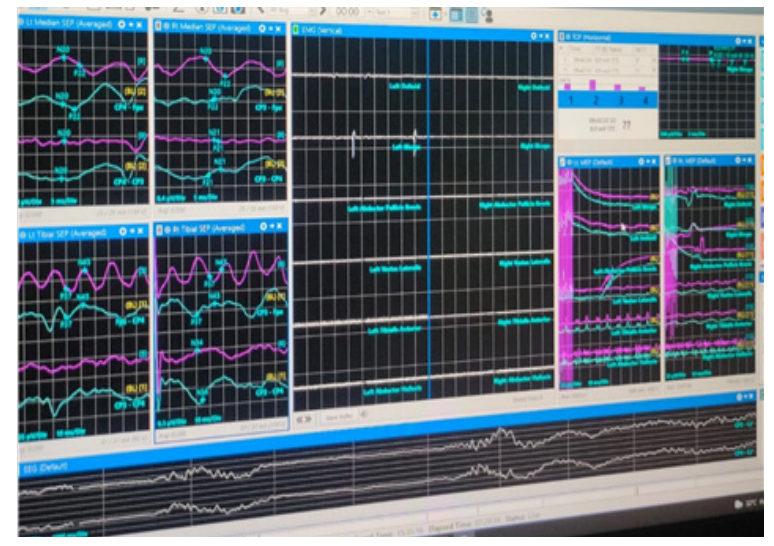

Gambar 3: Monitoring N-IOM Durante Operasi. Didapatkan monitoring gelombang SSEP disisi kiri monitor dan MEP disisi kanan monitor
APTT:25,1/27,3; Ur/Cr: 15,7/0,47). Weaning perlahan mulai dilakukan dengan target penyapihan kebutuhan support ventilator pasien

\section{Pembahasan}

Tindakan operasi terutama operasi bedah saraf membutuhkan kondisi pasien yang tenang, dan tersedasi dalam untuk menghindari peningkatan intrakranial baik saat dilakukan induksi maupun saat durante operasi. Tindakan anesthesia pada hampir semua jenis operasi diaplikasikan untuk mensupresi sistem fungsi motorik dan sensorik pasien selama tindakan operasi berlangsung, akan tetapi keadaan supresif tersebut, terutama pada operasi bedah saraf tidak dapat memberikan informasi klinis sedini mungkin kepada operator pada waktu yang tepat apabila terjadi suatu kerusakan saraf durante operasi. Banyak komplikasi yang dialami saat dilakukan tindakan surgery terutama tindakan didaerah susunan saraf pusat, salah satunya defisit neurologis post operasi. Oleh karena itu Intraoperatif Neurofisiologi Monitoring berperan penting dalam tindakan bedah saraf di era modern ini. Pada awalnya N-IOM pertama kali dipergunakan pada abad 19. Pada saat itu N-IOM digunakan untuk mendeteksi aktivitas saraf fasial dan kemudian dipergunakan juga elektroensefalografi untuk mendeteksi iskemia serebral, untuk pertama kalinya di tahun 1965. Meskipun IONM digunakan secara luas, dan banyak penelitian pusat tunggal telah dilakukan, tidak ada penelitian yang secara jelas mendefinisikan nilai tambah, dalam hal sensitivitas dan spesifisitas keseluruhan untuk mendeteksi atau mencegah kerusakan saraf. ${ }^{8}$ Pada era modern ini tujuan dari intraoperatif neurofisiologi monitoring adalah sebagai metode alternatif dalam membantu tindakan operasi disaat pasien sedang terbius total, dalam memonitoring dan menjaga sistem fungsi persarafan selama operasi berlangsung. ${ }^{4}$

Penggunaan IONM dalam operasi kelainan cervical telah semakin banyak digunakan. Saat ini, SSEP adalah teknik yang paling umum digunakan di antara modalitas IONM. Penggunaannya dalam operasi cervical tidak hanya terbatas untuk pemantauan kanal sensorik 
selama operasi tetapi juga untuk penilaian spinal cord dan spinal root setelah memposisikan pasien di meja operasi. Namun, karena spesifisitasnya yang dilaporkan rendah, perubahan SSEP selama operasi tidak selalu dikaitkan dengan defisit neurologis pascaoperasi. Akibatnya, banyak peneliti merekomendasikan untuk tidak menggunakannya sebagai modalitas pemantauan tunggal dalam prosedur cervical yang kompleks. ${ }^{5}$ Penggunaan Modalitas SSEP dikombinasikan dengan MEP dan EEG lebih memberikan data yang akurat daripada pemantauan tunggal dengan SSEP.

Pada dasarnya pemantauan saraf intraoperatif (N-IOM) mengacu pada penggunaan berbagai metode elektrofisiologis untuk memantau fungsi otak, sumsum tulang belakang, dan saraf terkait selama prosedur pembedahan. Contoh N-IOM termasuk brainstem auditory evoked potential (BAEP), Visual evoked potential (VEP), elektroensefalografi (EEG), elektromiografi (EMG), Motor evoked potential (MEP), atau Sensory/Somatosensory evoked potential (SEP). Masing-masing teknik ini melibatkan penggunaan rangsangan ke bagian tertentu dari sistem saraf, dan kemudian respons dicatat untuk menentukan apakah spesifik jalur itu berfungsi dengan baik, namun tidak semua prosedur bedah memerlukan semua monitoring IONM. ${ }^{4}$ Dalam pemantauan potensial listrik yang dibangkitkan, jalur saraf memaparkan stimulasi listrik di salah satu ujung jalur, dengan respons yang diukur di ujung lainnya dalam bentuk beda potensial (volt). Respon yang dibangkitkan diharapkan terekam dalam waktu tertentu (latensi) dari stimulasi dan menunjukkan kekuatan (amplitudo) dan pola tertentu (Gambar 4). Fitur-fitur ini penting dalam menggambarkan respons yang ditimbulkan. Setiap penurunan besar dalam amplitudo, peningkatan latensi, atau perubahan pola menunjukkan kemungkinan kompromisasi jaringan saraf. ${ }^{4}$ pada beberapa kasus ditemukan otot MEP hilang selama operasi sementara Amplitudo gelombang D setengahnya tetap ada maka diprediksikan defisit motorik karena operasi akan bersifat sementara sehingga operasi bisa diselesaikan. ${ }^{9}$

Pada kasus ini, tumor medula spinalis terjadi di dalam atau di dekat medula spinalis, dan merupakan $2 \%-4 \%$ tumor SSP. Tiga jenis tumor yang paling banyak ditemukan adalah meningioma, schwannoma, dan ependymoma. Schwannoma adalah yang paling umum $(45,5 \%$ kasus), diikuti oleh meningioma (18,7\%), dan ependymoma $(12,2 \%){ }^{1}$ Secara khusus, tumor saraf tulang belakang menyumbang persentase kasus tertinggi. N-IOM lebih sering dilakukan pada operasi function-sparing, dimana terdapat tumor jinak dan tumbuh lambat. Pada operasi eksisi tumor myelum, N-IOM jika dilihat secara fungsi anatomis, MEP memantau traktus kortikospinalis turun dari korteks motorik ke kornu anterior medula spinalis dan serabut saraf perifer. SSEP mewakili fungsi jalur kolumnalemniskal dorsal dari sistem somatosensori. Jalur tersebut terdiri dari korteks somatosensori, nukleus ventroposterior talamus, lemniskus medial, kolumna dorsalis, dan serabut saraf perifer. Demikian juga, jalur saraf SSEP terdiri dari sumsum tulang belakang dari bagian intramedullary dan serabut saraf perifer dari bagian ekstramedullary. Dengan demikian, kami menyarankan bahwa pemantauan neurofisiologis intraoperatif operasi tumor sumsum tulang belakang harus mempertimbangkan lokasi anatomi tumor. ${ }^{1}$ Oleh karena itu pada operasi kasus ini dilakukan 3 pemantauan dasar N-IOM yakni dengan MEP, SSEP dan EEG. Dimana saat durante operasi memang didapatkan 3

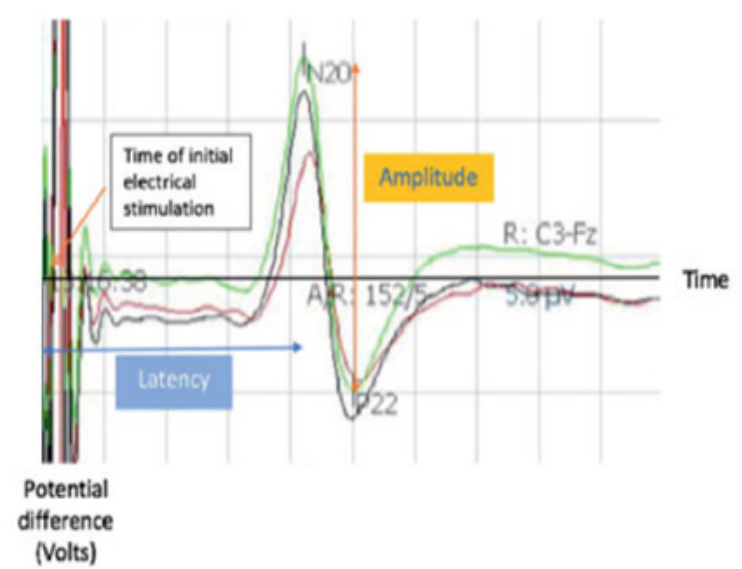

Gambar 4. Contoh respons yang dibangkitkan. Latensi (satuan: detik) dan amplitudo (satuan: volt) adalah parameter penting dalam menggambarkan potensi yang dibangkitkan 
Tabel 1. Pengaruh Agen Anestesi pada SSEP dan MEP

\begin{tabular}{lll}
\hline Anesthetic Agent & SSEP & MEP \\
\hline Volatile agents & $\begin{array}{l}\text { Supressed over } \\
\text { minimum alveolar } \\
\text { concentration }\end{array}$ & Supressed \\
Propofol & $\begin{array}{l}\text { Unchanged } \\
\text { Unchanged }\end{array}$ & $\begin{array}{l}\text { Unchanged } \\
\text { Supressed }\end{array}$ \\
Benzodiazepine & $\begin{array}{l}\text { Unchanged in } \\
\text { premedication } \\
\text { dose }\end{array}$ & Unchanged \\
Ketamine & $\begin{array}{l}\text { Enhanced } \\
\text { Cortical response } \\
\text { Etomidate }\end{array}$ & $\begin{array}{l}\text { Enhanced } \\
\text { Unchanged }\end{array}$ \\
Opioids & Unchanged & Unchanged \\
\hline
\end{tabular}

monitoring tersebut yang cukup responsif untuk memonitoring fungsi persarafan durante operasi.

Kami juga mengkategorikan kasus tumor sumsum tulang belakang berdasarkan tipe patologis. Beberapa tumor seperti schwannoma, hemangioma, dan neurofibroma biasanya merupakan bentuk jinak, sedangkan tumor lain seperti astrocytoma, multiple myeloma, tumor sel bulat kecil adalah bentuk ganas. Dalam kasus tumor sumsum tulang belakang jinak, reseksi radikal tumor biasanya dilakukan untuk tujuan kuratif. Di sisi lain, dalam kasus tumor ganas sumsum tulang belakang, reseksi tumor biasanya dilakukan untuk manajemen paliatif. ${ }^{1}$ Selain itu, kisaran invasi dalam prosedur pembedahan akan berbeda sesuai dengan tipe patologis dan anatomis tumor. Jika dilihat dari segi anestesi, Kebanyakan agen anestesi mengubah fungsi saraf dengan menghasilkan depresi yang bergantung pada dosis dalam aktivitas sinaptik. Secara umum, agen inhalasi memiliki efek yang lebih besar pada potensi yang ditimbulkan daripada agen anestesi intravena (Tabel 1). Pilihan dan dosis agen hipnotis ini harus disesuaikan dengan modalitas yang digunakan.

Agen inhalasi menyebabkan penurunan amplitudo tergantung dosis dan peningkatan latensi respons yang ditimbulkan. Untuk SSEP, efek tersebut lebih menonjol pada respons kortikal daripada respons subkortikal dan perifer. SSEP yang memadai biasanya dapat dicatat pada konsentrasi minimum alveolar.

Namun, untuk pasien dengan gangguan neurologis dasar atau neuropati akibat penyakit sistemik, tingkat agen inhalasi yang lebih rendah dapat menghilangkan potensi dan membuat pemantauan menjadi tidak mungkin. MEP dipengaruhi oleh konsentrasi agen volatil yang lebih rendah karena mereka menekan rangsangan neuron motorik yang lebih rendah secara lebih mendalam. BAEP dan EMG resisten terhadap agen inhalasi. ${ }^{7}$ Sinyal SSEP tidak terpengaruh oleh dosis barbiturat tinggi, sedangkan sinyal MEP sensitif terhadap barbiturat. Benzodiazepin yang digunakan pada dosis premedikasi tidak akan menekan SSEP dan MEP. Ketamin dapat meningkatkan respons SSEP dan MEP, yang mungkin bermanfaat untuk pemantauan bila digunakan untuk melengkapi anestesi atau analgesia. Etomidate dapat meningkatkan amplitudo rekaman SSEP kortikal tanpa mempengaruhi potensi yang ditimbulkan perifer atau respons subkortikal. ${ }^{4}$ Ada penelitian terbatas tentang efek dexmedetomidine pada potensi yang ditimbulkan, namun saat kami gunakan dexmedetomidine siringe $0,4-0,7 \mathrm{mcg} /$ jam tidak didapatkan adanya gangguan dalam perekaman SSEP, MEP dan EEG. Pada obatobatan induksi maupun sedasi, pilihan utama pada N-IOM bisa digunakan propofol. Dikenal karena profil farmakokinetik dan titratabilitasnya yang menguntungkan, propofol menekan SSEP dan MEP bergantung pada dosis tetapi pada tingkat yang jauh lebih kecil, memungkinkan pengukuran yang memadai pada dosis klinis yang umum digunakan. Ini dianggap sebagai agen anestesi pilihan untuk memfasilitasi IOM, terutama ketika pemantauan MEP digunakan. Sedangkan potensi yang dibangkitkan dapat direkam baik pada gelombang MEP maupun SSEP bahkan pada dosis opioid yang sangat tinggi, sehingga infus opioid kuat kerja pendek seperti fentanyl biasanya digunakan untuk mengurangi kebutuhan anestesi selama prosedur bedah yang melibatkan pemantauan potensi yang dibangkitkan. ${ }^{4,7}$

Pemantauan MEP dan EMG dipengaruhi oleh 
relaksan otot, yang menghambat aktivitas listrik melintasi sambungan neuromuskular, memengaruhi perekaman sinyal karena kontraksi otot tidak dapat lagi dihasilkan pada stimulasi saraf. Jika perekaman MEP atau EMG diperlukan segera setelah intubasi endotrakeal, seseorang dapat memberikan dosis relaksan otot kerja pendek sebelum laringoskopi dan membiarkan efeknya hilang sebelum pemantauan dimulai. Jika perlu, agen reverse juga dapat diberikan sebelum pemantauan N-IOM dimulai. Oleh sebab itu pada kasus ini kami memakai kombinasi propofol 250-350mg/jam, fentanyl $50-100 \mathrm{mcg} / \mathrm{jam}$ dan dexmedetomidine siringe $0,4-0,7 \mathrm{mcg} / \mathrm{jam}$. Dengan kombinasi ketiga obat itu untuk menjaga kedalaman anestesi durante operasi maka kita dapatkan hemodinamik yang relatif stabil pada pasien namun tidak mempengaruhi monitoring $\mathrm{N}-\mathrm{IOM}$ oleh tim neurologi.

Namun selain dari faktor obat-obat anestesi terdapat beberapa faktor fisiologis yang perlu diperhatikan karena dapat mempengaruhi pemantauan potensial yang ditimbulkan. Pasokan oksigen yang tidak memadai untuk memenuhi kebutuhan metabolisme jaringan saraf adalah salah satu penyebab utama perubahan sinyal patologis yang terlihat pada rekaman potensi yang dibangkitkan (yaitu peningkatan latensi atau penurunan amplitudo). ${ }^{6}$ Pasokan oksigen ke otak tergantung pada kandungan oksigen darah yang memadai dan perfusi serebral, yang pada gilirannya dipengaruhi oleh tekanan darah sistemik dan diameter pembuluh intrakranial. Penurunan pasokan oksigen biasanya dipengaruhi oleh penurunan tekanan darah sistemik atau regional, hiperventilasi dan hipokapnia yang dihasilkan dapat menyempitkan pembuluh darah otak dan mengurangi pengiriman oksigen serta anemia dan hipoksemia mengurangi kandungan oksigen darah. Oleh sebab itu tingkat keberhasilan perekaman N-IOM selain dipengaruhi oleh pemilihan obat-obatan anestesi juga dipengaruhi oleh faktor-faktor fisiologis terutama berubungan dengan perfusi jaringan system saraf pusat.

\section{Simpulan}

N-IOM merupakan prosedur pendamping tindakan anestesi pada neurosurgery yang dapat menawarkan opsi yang menarik untuk pemantauan sistem saraf secara real-time, tetapi implementasi yang berhasil harus dibangun di atas pendekatan tim untuk memfasilitasi IOM dan tindakan korektif yang tepat ketika perubahan sinyal besar terjadi. Ahli anestesi memainkan peran penting dalam mengevaluasi dampak anestesi dan fisiologi pada sinyal IOM dan mengoptimalkan faktorfaktor ini secara intraoperatif. Teknik N-IOM dengan menggunakan sedasi seperti Propofol dan Dexmedetomidine yang dikombinasikan dengan Opioid dapat menjaga kedalaman anestesi pasien tanpa mengganggu sinyal N-IOM itu sendiri. Namun tidak semua teknik N-IOM menggunakan regimen yang sama. Hal itu dipengaruhi oleh variasi status neurologis premorbid pasien, jenis anestesi, pengaturan neuromonitoring, dan sifat serta pendekatan pembedahan. Begitu juga dengan pemilihan sinyal neuromonitoring yang akan direkam. Terbukti perekaman SSEP dan MEP merupaka indikator paling sensitif yang bisa digunakan pada operasi di daerah tulang belakang. Namun pemilihan sinyal N-IOM juga dipengaruhi oleh variasi status neurologis premorbid pasien, ketersediaan alat dan sifat serta pendekatan pembedahan oleh operator. Oleh sebab itu setiap institusi dapat mengembangkan protokolnya sendiri tentang apa dan bagaimana memantau dan sejauh mana perubahan sinyal merupakan kriteria perubahan yang signifikan, membuat komunikasi di antara personel intraoperatif menjadi vital.

\section{Daftar Pustaka}

1. Park T, Park J, Ghil Park Y, Lee J. Intraoperative neurophysiological monitoring for spinal cord tumor surgery: Comparison of motor and somatosensory evoked potentials according to tumor types. Ann Rehabil Med. 2017 Aug; 41(4): 610-620.

2. Scibilia A, Terranova C, Rizzo V, Raffa G, Morelli A, Esposito F, et al. Intraoperative neurophysiological mapping and monitoring in spinal tumor surgery: sirens or indispensable tools?. Neurosurg Focus. 2016 Aug; 41(2):E18. 
3. Sendjaja M. Peran Intraoperatif neurofisiologi monitoring dalam penatalaksanaan penyakit peredaran darah otak. Staf Departemen Neurologi RS. Medistra, Jakarta, Indonesia. 2017

4. Wing-hay HY, Chun-kwong EC. Introduction to intraoperative neurophysiological monitoring for anaesthetists. General Anaesthesia. World Federation of Societies of Anestesiologist. 2019 August; 397

5. Charalampidis A, Jiang F, Wilson RFJ, Badhiwala HJ, Brodke DS, Fehlings, MG. The use of intraoperative neurophysiological monitoring in spine surgery. Global Spine Journal. January 6, 2020.

6. Santosa D, Harijono B. Pengelolaan anestesi untuk eksisi tumor intradura intramedula (IDIM) setinggi vertebra cervical 5-6 dengan panduan intraoperative neurophysiological monitoring. JNI.2018;7(3): 164-74.

7. You $\mathrm{H}$, Qiao $\mathrm{H}$. Intraoperative neuromonitoring during resection of gliomas involving eloquent areas. Department of Neurophysiology, Beijing Neurosurgical Institute, Capital Medical University, Beijing, China. Front. Neurol. 23 June 2021.

8. K Rijs, Klimek M, Scheltens-de Boer M, Biesheuvel K, Harhangi BS. Intraoperative neuromonitoring in patients with intramedullary spinal cord tumor: A Systematic Review, Meta-Analysis, and Case Series. World Neurosurgery. 2019, 127: 66263

9. Aydınlar EI, Dikmen PY, Silav G, Berkman MZ, Elmaci I, Ozgen S. Intraoperative neurophysiological monitoring to prevent new. Neurological Deficits in Spinal Tumor Cases

10. Mullatti N, Coakhamb HB, Maw AR, Butler $\mathrm{SR}$, Morgan $\mathrm{MH}$. Intraoperative monitoring during surgery for acoustic neuroma: benefits of an extratympanic intrameatal electrode. Journal of Neurology, Neurosurgery and psychiatry. 2016; 66 (5). 